\title{
Economic Effects of the Digital Transformation on the Banking Market Using the Example of Savings Banks and Cooperative Banks in Germany
}

\author{
Carsten Giebe ${ }^{1} \&$ Kevin Schulz ${ }^{2}$ \\ ${ }^{1}$ Szent István University, Faculty of Economic Science, Doctoral School in Management and Organizational \\ Sciences, Kaposvár, Hungary \\ ${ }^{2}$ FOM, Hochschule für Oekonomie \& Management, University of Applied Sciences, Berlin, Germany \\ Correspondence: Carsten Giebe, Szent István University, Kaposvár Campus, Faculty of Economic Science, Guba \\ Sándor u. 40, H-7400 Kaposvár, Hungary. E-mail: carsten.giebe@ ke.hu
}

Received: March 11, 2021

Accepted: April 14, 2021

Online Published: May 10, 2021

doi:10.5539/ijef.v13n6p34

URL: https://doi.org/10.5539/ijef.v13n6p34

\begin{abstract}
Due to the digital transformation, the banking sector in Germany is undergoing massive change. This structural change is massively influenced by technological progress, regulation and supervision, the low-interest phase and demographic change. The focus of this research is on the comparison of savings banks and cooperative banks in Germany, as there are many similarities between the two banking groups. Both belong to the so-called retail banks. The respective bank clients are very similar due to the regional principle, the structure in regional associations and in their clientele. The main purpose of this research is to investigate which of the two banking groups, savings banks or cooperative banks, is more operationally efficient under the same prevailing competitive pressure from the Digital Transformation. This paper summarises the analysis of both banking groups based on real ratios. The relevance of the findings on this scientific problem is that the comparison of savings banks and cooperative banks in Germany has not been addressed in the scientific literature so far. The aim of the research is to make a statement as to which banking group has performed better given the same external market factors. Furthermore, arguments and counter-arguments within the academic discussion on the topic of digitalization in the German banking market will be compiled. The results of the research can be useful for academics who deal with the digital transformation in the banking sector in Germany.
\end{abstract}

Keywords: competition, digital transformation, savings banks, cooperative banks

\section{Introduction}

In the last decade, the influence of new digital technologies has had a major impact. The so-called digital transformation describes the integration of digital technologies into business processes (Liu et al., 2011). In many sectors, from industry to science, one can observe a "digital transformation" along the various value chains (Kauffmann \& Weber, 2018). The integration and use of new digital technologies is one of the biggest challenges that companies face. It often leads to the transformation of entire business models (Hess et al., 2016).

The banking sector is undergoing the greatest structural upheaval the industry has ever experienced. This structural change is being driven massively by technological progress. Banks are forced to strategically reposition themselves. Until now, banks have been able to achieve high market penetration with standard products. Innovative product ideas are necessary, as banks appear on the market with almost identical products. A high level of transparency in banking services has led to increased service and quality demands on the part of customers. The values of bank customers are also changing rapidly. For optimal customer service, an individual conceptualisation of the business relationship is necessary. It is becoming easier for non-banks to enter the previously lucrative business areas of banks. Banks are being forced to provide highly efficient banking services, and large personnel and material expenses are creating increasing cost pressure (Moormann, 2000).

The banking sector in Germany is divided into a three-pillar structure. The first pillar includes private commercial banks, such as Deutsche Bank and Commerzbank. The second pillar includes the public institutions, Landesbanken and the savings banks (aka Sparkassen). The third and last pillar symbolises the cooperative banks (aka Genossenschaftsbanken), such as the Volks- und Raiffeisenbanken (Hammerström et al., 2019). The 
focus of this research is to compare cooperative banks and savings banks (see Figure 1). There are many similarities between the two banking groups. Both belong to the so-called retail banks. The respective bank customers are very similar due to the regional principle, the structure in regional associations and in their clientele.

\section{The three pillars of the German banking system}

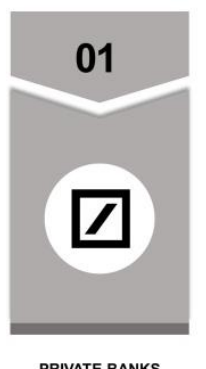

PRIVATE BANKS

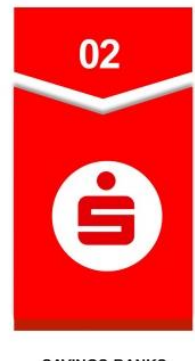

SAVINGS BANKS
(SPARKASSEN)

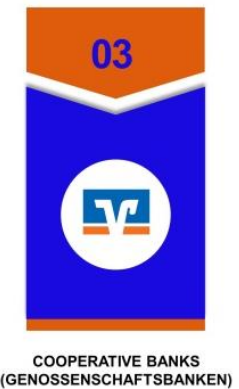

COOPERATIVE BANKS
(GENOSSENSCHAFTSBANKEN)

Figure 1. Own representation of the "Three Pillar Structure of the German Banking System"

Savings banks are institutions under public law. As a rule, they belong to cities or municipalities. Savings banks were originally created to enable the poorer urban population to participate in banking transactions. They serve the common good. Accordingly, their profits must also serve the common good, for example for charitable purposes. Savings banks have a public mandate; they are supposed to promote savings and asset accumulation among the population. Many savings banks in Germany could miss the boat in the age of digital transformation. On the one hand, external influences such as customer expectations, customer behaviour, willingness to pay, technological change and product life cycles are becoming more important. On the other hand, internal expectations of one's own employees regarding adaptation to new processes or acceptance of new technological solutions will increase. In the future, the working world will be characterised by automation and digitalization. Savings banks are forced to digitalize their processes due to low returns. Innovative banking services must be tested for feasibility and then embedded in processes. It is an open secret that cost reductions are realised through a higher degree of automation (Giebe, 2019).

Cooperative banks are credit institutions whose objective, according to their statutes, is the economic promotion of their members through joint business operations. Historically, they have their origins in purchasing cooperatives and lending associations. In Germany, cooperative banks are primarily the Volksbanken and Raiffeisenbanken. In the middle of the 19th century, Raiffeisenbanken were founded by Friedrich-Wilhelm Raiffeisen for the agricultural sector. The Volksbanks were founded by Hermann Schulze-Delitzsch for the commercial SME sector as self-help organisations.

The cooperative banks also face the current challenges already mentioned. They are also influenced by regulation and supervision, the low-interest phase, digitalization and demographic change. According to Arts (2016), these are not only developments within the banking market, but also global developments. These increase the already existing intensity of competition in the German banking market. Increasing regulation and banking supervision as well as the low-interest phase are leading to falling revenues and rising costs. There are also threats to cooperative banks from fintech companies due to increasing digitalization (Arts, 2016).

\section{Literature Review}

Within the scope of an explorative literature research, numerous attempts were made to examine the effects of digitalization or digital transformation using the example of the German banking sector. The focus of the research was placed on the savings banks and cooperative banks. Although the situation of individual banks and bank groups is presented in the literature, it should be noted that a comparison of these two bank groups has not been addressed in the academic literature in the recent past. In the literature review, three main categories can be defined, which we have used to prepare this article.

The first category of literature deals with the banking market in Germany and specifically with the role of the savings banks and the cooperative banks. Studies on the situation of these German credit institutions broadly emphasise the importance of imperative strategies. Arts 2016, Damaschke and Giebe 2020 and Wolgast 2016 should be mentioned as examples of literature in this category, which allows discussion of the necessary framework for assessing the situation. The second category of literature is essentially scientific work that deals 
with the digital transformation. Several studies have shown that the digital transformation has also made its way into the banking and financial services sector and has left clear traces. Literature that has enabled us to identify necessary background on the impact of digitalization are Hess et al. (2016), Ilie et al. (2017) and Sebastian et al. (2019). The third category in this section includes necessary data that we need to investigate the two banking groups, those of savings banks and cooperative banks. These are data sets that provide us with information on the number of institutions, the number of branches, the number of employees and key business figures of these two banking groups in Germany. Previous studies have shown that the banking market in Germany has been struggling with strong effects on the cost side for almost 20 years.

\section{Research Question}

Which of the two banking groups, savings banks or cooperative banks, is more operationally efficient given the same prevailing competitive pressure from the digital transformation?

\section{Methodology and Hypotheses}

In order to answer the research question, research was conducted on the internet and various datasets were identified on https://de.statista.com/. Statista is a German online portal for statistics that makes data accessible. The following data was used for our research and limited to the period 1999-2018:

- Number of savings banks in Germany

- Number of Volksbanken and Raiffeisenbanken in Germany

- Number of branches of savings banks in Germany

- Number of bank branches of Volksbanken and Raiffeisenbanken in Germany

- Number of employees at savings banks in Germany

- Number of employees of Volksbanken and Raiffeisenbanken in Germany

- Operating result of Savings Banks in Germany

- Operating profit of the cooperative banks in Germany

- Return on Equity after Taxes of Savings Banks in Germany

- Return on equity after taxes of the cooperative banks in Germany

- Development of the Cost-Income Ratio of the Savings Banks in Germany

- Development of the Cost-Income Ratio of the Cooperative Banks in Germany

In addition to the number of institutions, branches and employees of both banking groups, business ratios were used in this research. Here, the key figures operating profit, return on equity and cost-income ratio were used. The operating result is a business ratio and usually refers to the result from ordinary business activities. In the case of banks and savings banks, in simplified terms, it is the balance of expenses and income from operating business. The return on equity is an indicator of the earnings situation of a credit institution that shows the result (net income after taxes) in relation to the equity capital employed. The cost-income ratio is an economic indicator in the operative business of banks and provides information about the efficiency of a bank. The lower the cost-income ratio, the more efficiently the bank operates.

\subsection{In the Context of This Research, the Following Hypotheses Are Put Forward}

\section{1). Hypothesis}

$\mathbf{H}_{\mathbf{0}}$ : The difference between savings banks and cooperative banks is not significant in terms of operating profitability as measured by return on equity from 1999 to 2018 .

\section{2). Hypothesis}

$\mathbf{H}_{\mathbf{0}}$ : The difference between savings banks and cooperative banks is not significant in terms of operating profitability as measured by the cost-income ratio in the years 1999 to 2018.

\subsection{Descriptive Analyses}

The number of institutions is continuously decreasing for the savings banks and cooperative banks (see Figure 2). In contrast to the savings banks, the cooperative banks have reduced their number of institutions significantly stronger until 2008; an acceleration is visible from 2014 onwards. In the case of the savings banks, a stabilisation of the number of institutions can be seen from 2018 onwards. 


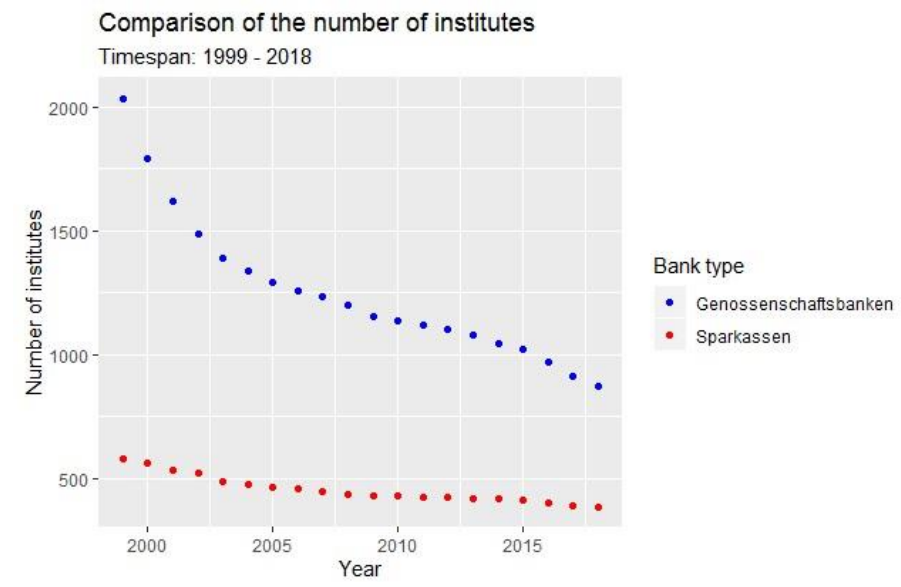

Figure 2. Own representation of the "Comparison of the number of institutes"

For better comparability, a logarithmic transformation was applied (see figure 3). It can be seen that the temporal developments were similar, apart from the different starting levels.

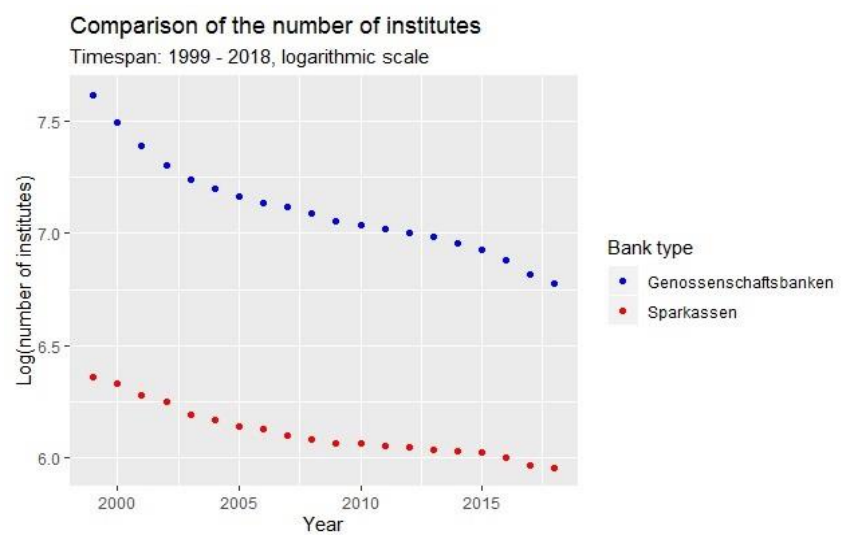

Figure 3. Own representation of the "Comparison of the number of institutes"

(logarithmic transformation)

The number of branches is continuously decreasing for the savings banks and cooperative banks (see Figure 4). The savings banks and cooperative banks also take a very similar development with a comparable starting position. The reduction of branches is initially very rapid, flattening out in 2008, then rapid again. Cooperative banks even kept their branch numbers constant in 2008. For both bank groups, savings banks and cooperative banks, a clear downward trend is evident. The flattening / stagnation around 2008 is probably due to the global economic crisis. Both banks seem to have scaled back their transformative processes here.

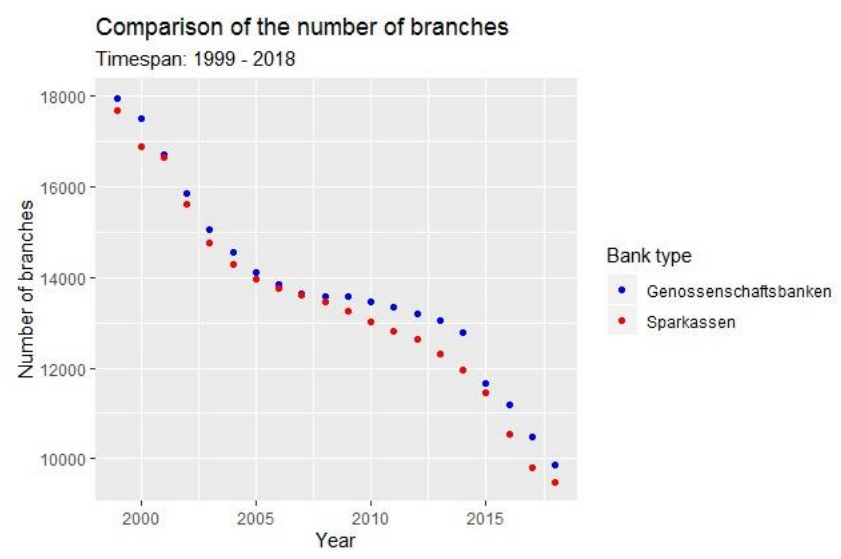

Figure 4. Own representation of the "Comparison of the number of branches" 
Savings banks and cooperative banks have a different starting level but a similar development (see Figure 5). Job cuts have been taking place since the beginning of the 2000s, with an acceleration since 2014. The savings banks are cutting jobs with greater intensity after the number of employees was still growing around the turn of the millennium. Cooperative banks stabilised the number of employees in 2008 , then continuously reduced it again.

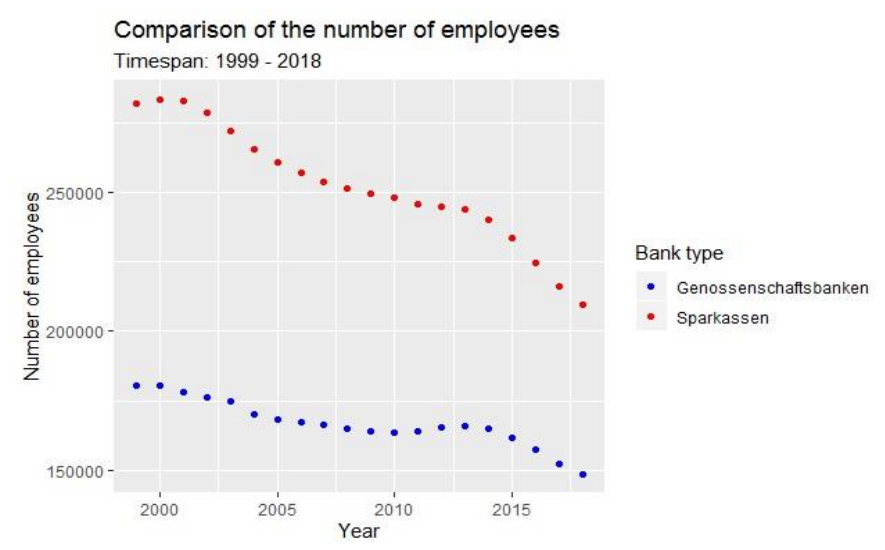

Figure 5. Own representation of the "Comparison of the number of employees"

For savings banks and cooperative banks, a continuous increase in operating profit (see Figure 6) is evident. Both bank groups do not show major differences except for the different starting level. In 2011, an outlier can be seen at the savings banks. In 2008, there was a slump in the operating result at savings banks and cooperative banks.

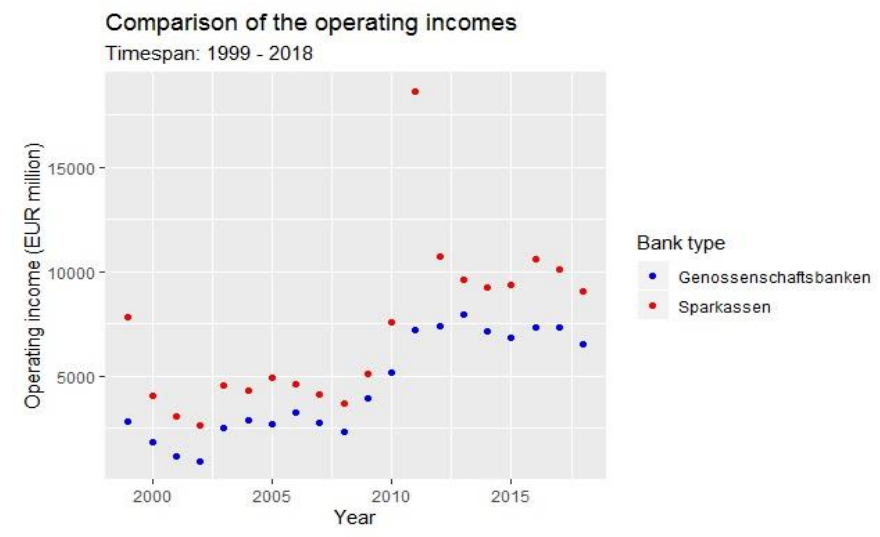

Figure 6. Own representation of the "Comparison of the operating incomes"

\subsection{Statistical tests}

\section{1). Hypothesis}

$\mathbf{H}_{\mathbf{0}}$ : The difference between savings banks and cooperative banks is not significant in terms of operating profitability as measured by return on equity from 1999 to 2018 .

\section{2). Hypothesis}

$\mathbf{H}_{\mathbf{0}}$ : The difference between savings banks and cooperative banks is not significant in terms of operating profitability as measured by the cost-income ratio in the years 1999 to 2018.

\subsection{Methodological Approach}

A linear regression was used to model the relationship between time and the banking sector with the return on equity or the cost-income ratio. The banking sector was binary coded with savings banks $=1$ and cooperative banks $=0$ and an interaction term of the type "year x banking sector":

Return on equity $=a^{*}$ year $+b^{*}$ banking sector $+c^{*}$ year*banking sector $+d+$ noise, cost-income ratio $=\mathrm{A} *$ year $+\mathrm{B}$ *banking sector $+\mathrm{C}^{*}$ year*banking sector $+\mathrm{D}+$ noise, to explain the influence of the banking sector on the target value over time. 
Since the residuals in such a time series problem were not expected to satisfy the classical Gauss-Markov assumptions, especially because of heteroskedasticity and autocorrelation, the regression parameters were tested with a robust HAC (heteroskedasticity and autocorrelation consistent) variance estimator.

Apparently, there is no difference when comparing the return on equity of savings banks and cooperative banks (see Figure 7). The year 2011 is excluded from this analysis, as the high return on equity of the savings bank is to be considered an outlier.

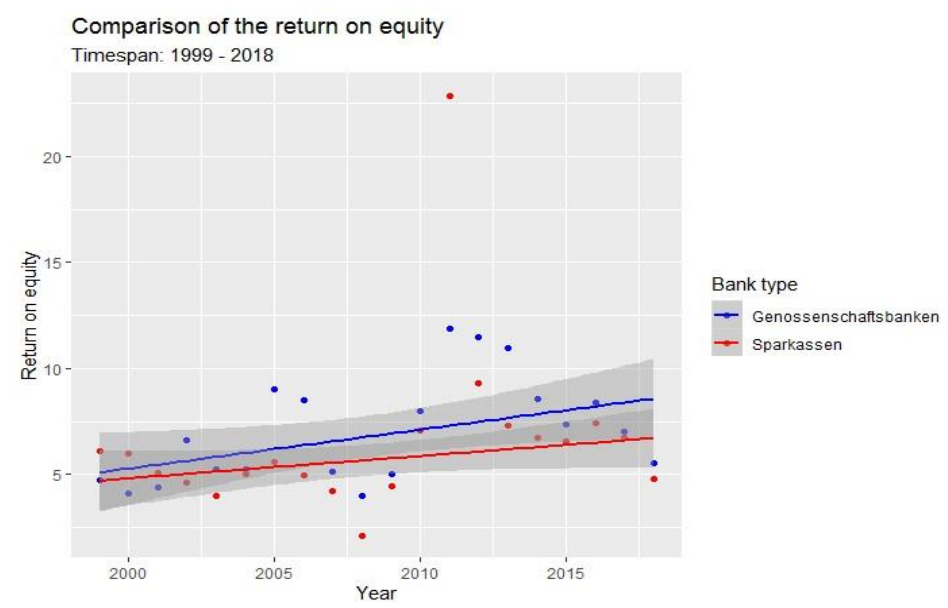

Figure 7. Own representation of the "Comparison of the return of equity"

1). Test

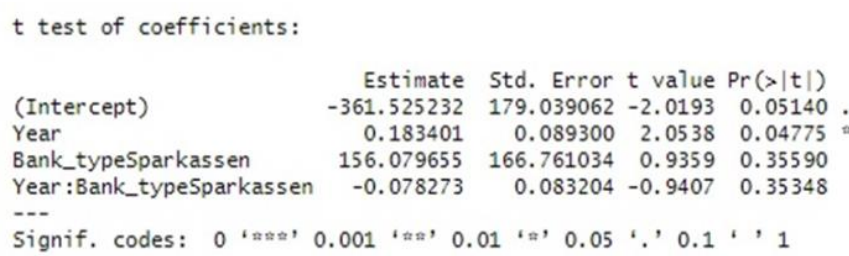

The interaction term "Year:Bank_typeSavings banks" has a p-value of 0.356 and is thus not significant (at alpha $=0.05$ ) - the hypothesis that savings banks and cooperative banks have not developed significantly differently in terms of return on equity cannot be rejected. From the p-value of Year $=0.047$ it can be concluded that the return on equity has increased significantly over the years. However, caution is required here, as the simultaneous evaluation of several parameters provokes the problem of multiple testing. With a conservative approach of alpha $=0.05 / 2=0.025$, the observation already disappears in statistical noise.

Apparently, the cost-income ratio has decreased strongly for cooperative banks, while it has remained constant for savings banks (see Figure 8). This is interesting, as comparable cost-cutting measures have been initiated.

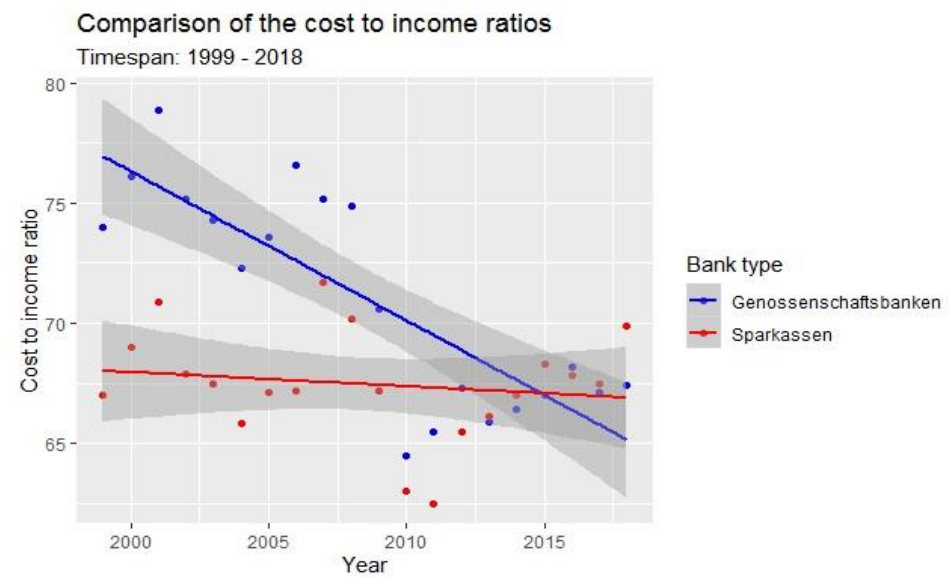

Figure 8. Own representation of the "Comparison of the cost to income ratios" 
2). Test

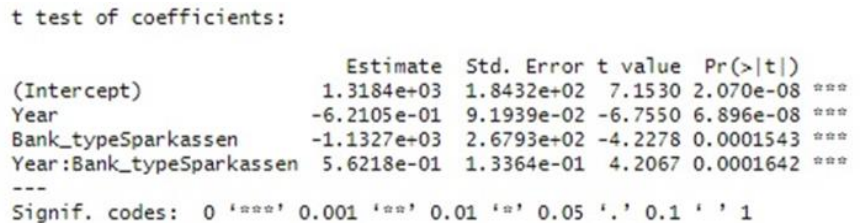

The hypothesis can be rejected: there is a statistically significant difference in the development of the cost-income ratio. For the savings banks, the cost-income ratio shrank on average by $0.621-0.5622=0.0588$ percentage points each year. For the cooperative banks, the cost-income ratio shrank on average by 0.621 percentage points each year. This shrinkage rate is also significant (see "Year" under coefficient: t-value=-6.398 has p-value of almost 0 ).

\subsection{Justification for Statistical Tests}

Both residual plots show that the residuals should by no means be assumed to be independent and identically normally distributed. Figure 9 shows a strong autocorrelation of the residuals from 2010 onwards.

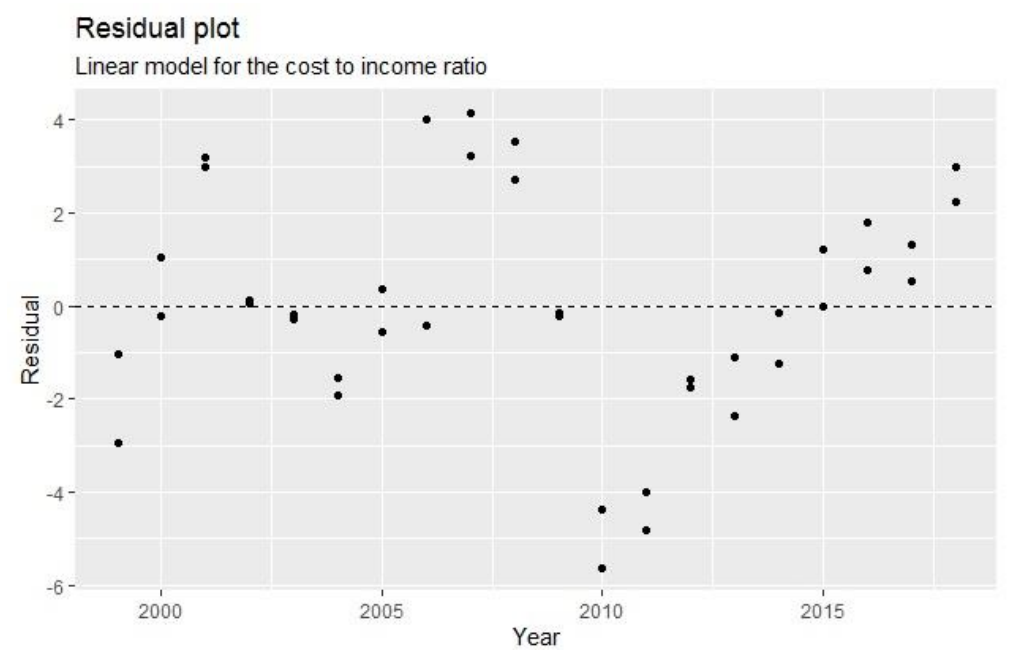

Figure 9. Own representation of the "Comparison of the cost to income ratios"

In Figure 10, heteroskedasticity is clearly visible in the funnel-shaped dispersion of the residuals. These residual plots underline the use of the more flexible HAC approach.

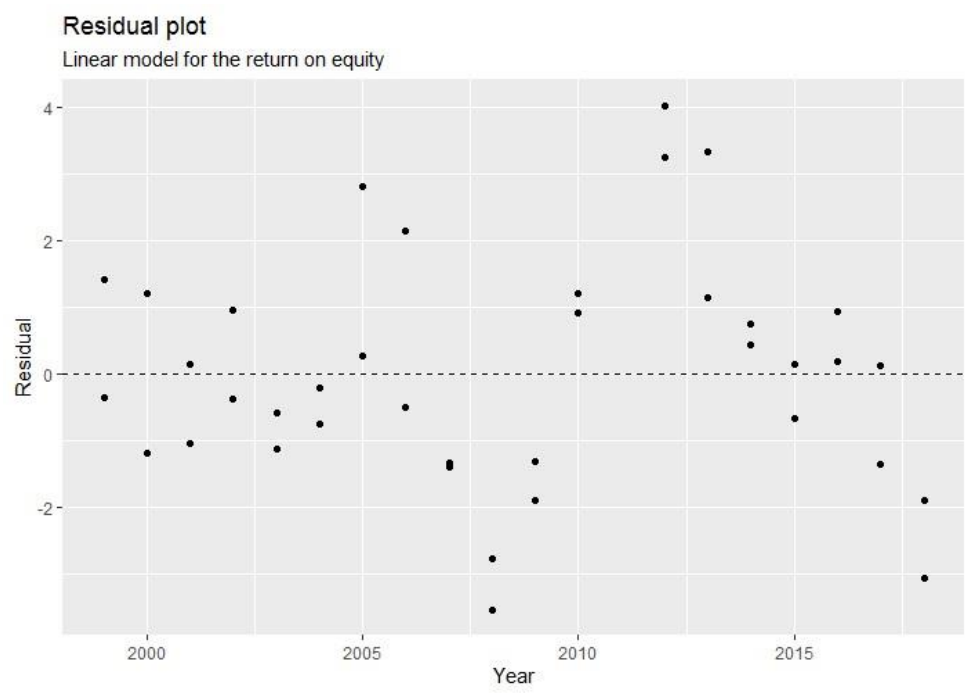

Figure 10. Own representation of the "Comparison of the return on equity" 


\section{Results and Discussion}

As has been worked out, savings banks and cooperative banks have reduced the number of institutions, branches and employees in a comparable way. Only the initial level differs. It allows the assumption that both bank groups have initiated comparable cost reduction measures. The operating result has also developed comparably. Incidentally, it is remarkable how similar the curves are. Nevertheless, no significant difference can be found in the development of the return on equity, so the first hypothesis cannot be rejected. It was striking that a statistically significant difference could be found in the cost-income ratio. In this respect, the second hypothesis can be rejected and answered in favour of the research question. Cooperative banks operate more economically than savings banks in Germany, despite the same prevailing competitive pressure due to the digital transformation.

The reasons for the change are different. For many years, for example, a trend of decreasing nominal and real interest rates has been observed in the most important industrialised countries in Europe. The result is a historically unprecedented environment of low and negative interest rates in the euro area and in Germany. The current ultra-low interest rate environment is putting considerable pressure on banks and savings banks in Germany to act (Wolgast, 2016). Banks in Germany are forced to digitalize their processes due to low yields. The consulting firm McKinsey even expects the return on equity to decline if the digital transformation is not implemented properly (Drummer et al., 2016). To counteract this trend, banks and savings banks are increasingly turning to mergers, staff cuts and branch closures to reduce costs. The President of the Federal Association of German Bank, Hans-Walter Peters, assumes that up to a quarter of the branches of all banks and savings banks in Germany will be closed in the next few years (Peters, 2018).

Savings banks and cooperative banks are forced to act and use options that were unthinkable years ago. In current practice, one can even speak of a paradigm shift. In the German state of Hesse, there is for the first time a cooperation between a cooperative bank and a savings bank. The fact that both institutions come from different banking groups and are competitors seems to be taken into account. The Frankfurter Volksbank and the Taunussparkasse are merging branches on a large scale due to the pressure to save money in Hesse. The joint branches are to be open on four days of the week: Sparkasse customers will be served on two days, Volksbank customers on the other two days. Customers will be able to tell which institution is represented by different lighting - sometimes red for the Sparkasse, sometimes blue for the Volksbank. Basic services such as cash withdrawals are to be offered to all customers via ATMs. This guarantees cost reductions and a presence in the area at the same time. This example is a novelty and could find imitators (Arnold, 2020).

\section{Conclusions}

The pressure on retail banks is enormous. Digital transformation offers extraordinary opportunities for traditional players and new entrants. In this context, innovation in the customer experience is essential. Process optimisation is considered a prerequisite for economic success. To seize the opportunities of the digital economy, traditional banks need to become digital banks to a large extent (Ilie et al., 2017). However, the digital strategy of a savings bank or a cooperative bank only has added value if it promotes investment and pools resources at the same time. Top management of many companies are reluctant to define a digital strategy. The best digital strategies simultaneously guide strategic as well as operational decisions (Sebastian et al., 2017).

The banking sector would benefit from the development of different competences. Commercial banks need to develop their own competencies for each activity in the value chain. This is the only way to make the best use of the various technological innovations. Effective and proactive competency-based management should be provided. This is the only way to ensure the availability of required competencies. One of the biggest challenges in the financial sector at present is the development of these specific competencies. The ultimate goal is to ensure their own competitiveness and sustainable business. Currently, a change in the demand for new solutions and technological competences of banks can be observed (Mavlutova \& Volkova, 2019).

When talking about technological innovations, the term Big Data \& Business Analytics cannot be missing. If we look at the perspective of bank customers in Germany, for example, Big Data \& Business Analytics can be an effective element according to a study by Giebe et al. (2019). In this study, most survey participants agreed with the statement that Big Data \& Business Analytics can ensure more objective, comprehensive, individualised and active advice. Furthermore, it was shown that Big Data \& Business Analytics can increase customer loyalty from the perspective of bank customers (Giebe et al., 2019). In this respect, Big Data \& Business Analytics should be mentioned as one of many possible technological innovations that should be taken into account in future digitalization projects.

This is accompanied by increasing demands on the skills, abilities and knowledge of employees. Employees are 
required to leverage the potential of digital technologies to increase the efficiency of work processes. The demands on employees' social competences are also increasing in the digital transformation. The systematic analysis of employee competence profiles helps managers to empower employees for upcoming changes. In a digitalized environment, a working environment conducive to learning, mixed-age teams and knowledge transfer systems contribute to success. The necessary professional and company experiential knowledge can thus be built up, maintained, developed further and passed on to others (Hammermann \& Stettes, 2016).

On the one hand, digitalization acts as two major development streams externally in the context of changing employee-customer contact. And on the other hand, digitalization on the inside with new internal processes and communication channels within a bank or savings bank. A real competitive advantage can be generated by successfully linking the classic attitudes of an advisor with the opportunities of digitalization (Damaschke \& Giebe, 2020).

Faced with the challenge of digital transformation and the need to remain competitive, business leaders need to formulate and implement strategies that drive the impact of digital transformation and better operational performance. Digital transformation is a highly complex, enterprise-wide effort. A systematic approach to formulating a digital transformation strategy remains critical for success (Hess et al., 2016).

\section{Limits and Directions for Further Research}

It is a very interesting fact that savings banks and cooperative banks have implemented cost-cutting measures to the same extent by reducing the number of institutions, branches and employees. However, in contrast to the savings banks, the cost-income ratio of the cooperative banks has been greatly reduced, while it has remained constant at the savings banks. This represents a research gap for further studies to specifically interrogate this fact.

In this research, only a selection of business ratios was used, so that it might be appropriate to examine even more ratios. The time series are a selection and limited to the year 2018, and these periods could also be extended in the context of further research. Furthermore, the datasets are historical and can therefore never depict the future in concrete terms. It would be exciting to observe in the context of further research to what extent the trend will continue over the next few years, also due to possible effects (such as COVID-19). A comparison with other industries and market participants might also be useful in order to draw conclusions about the influence of digitalization in other industries with a classic point of sale.

To analyse the positioning of banks for the future, Menrad (2020) wrote in his study about the evaluation of omni-channel management in banking. It found that banks are already thinking hard about introducing omni-channel concepts in banking. An introduction is even of fundamental importance for banking. The analysis based on expert interviews shows that the customer requirements of their bank do not allow any alternative to the implementation of an omni-channel concept. Banks are also lagging behind other industries in this context. Omni-channel management in German bank distribution will change significantly (Menrad, 2020). Existing omni-channel concepts of savings banks and cooperative banks could also be analysed in the context of further research using concrete key figures.

Conrad et al. investigated the physical and digital access to financial services of the public savings banks in Germany. The aim was to examine whether the closure of branches can be compensated for by digital offerings. A comparison of both measures of access to financial services shows that especially inhabitants of sparsely populated rural regions have both comparatively poor physical and below-average digital access. This regional gap will continue to grow, as the population in these regions will age and shrink at an above-average rate over the next few years, meaning that further branch closures are imminent, especially in these areas. In this respect, the savings banks are challenged to shape the transition from a predominant use of physical access to an exclusive or hybrid use of digital access accordingly. It must be questioned to what extent the savings banks will succeed in providing basic financial services digitally in a timely manner and across the board (Conrad et al., 2017). Demographic effects could also be further investigated in a comparison between savings banks and cooperative banks.

\section{References}

Anzahl der Bankstellen von Volksbanken und Raiffeisenbanken in Deutschland in den Jahren von 1970 bis 2019 [Number of bank offices of Volksbanken and Raiffeisenbanken in Germany between 1970 and 2019]. Retrieved March 
Anzahl der Beschäftigten bei Sparkassen in Deutschland in den Jahren von 1991 bis 2018 [Number of employees at savings banks in Germany between 1991 and 2018]. Retrieved March 2021 from https://de.statista.com/statistik/daten/studie/157024/umfrage/beschaeftigte-in-sparkassen-seit-dem-jahr-200 $0 /$

Anzahl der Beschäftigten bei Volks- und Raiffeisenbanken sowie bei Sparda-Banken in Deutschland von 1991 bis 2018 [Number of employees at Volksbanken and Raiffeisenbanken as well as Sparda banks in Germany from 1991 to 2018]. Retrieved March 2021 from https://de.statista.com/statistik/daten/studie/157028/umfrage/beschaeftigte-in-volks-und-raiffeisenbanken-so wie-sparda-banken-seit-2000/

Anzahl der Sparkasseninstitute und ihrer inländischen Zweigstellen in den Jahren von 1990 bis 2019 [Number of savings bank institutions and their domestic branches in the years 1990 to 2019]. Retrieved March 2021 from

https://de.statista.com/statistik/daten/studie/6698/umfrage/anzahl-der-sparkassen-und-inlaendischen-zweigst ellen-seit-dem-jahr-1990/

Arnold, A. (2020). "Volks-Sparkasse": Gemeinsame Filialen als Antwort auf den Spardruck ["Volks-Sparkasse": Joint branches in response to savings pressure] In FOCUS Online. Retrieved from https://www.focus.de/finanzen/banken/volks-sparkasse-gemeinsame-filialen-als-antwort-auf-den-spardruck _id_11090237.html

Arts, V. (2016). Aktuelle Herausforderungen für Genossenschaftsbanken: Eine Analyse der Umwelt [Current challenges for cooperative banks: An analysis of the environment]. Arbeitspapiere des Instituts für Genossenschaftswesen der Westfälischen Wilhelms-Universität Münster (No. 163). Retrieved from http://hdl.handle.net/10419/129624

Betriebsergebnis der Genossenschaftsbanken in Deutschland in den Jahren von 1999 bis 2018 (in Millionen Euro) [Operating profit of cooperative banks in Germany in the years 1999 to 2018 (in millions of euros]. Retrieved March 2021 from https://de.statista.com/statistik/daten/studie/217984/umfrage/betriebsergebnis-deutscher-kreditgenossenscha ften-seit-1999/

Betriebsergebnis der Sparkassen in Deutschland in den Jahren von 1999 bis 2018 (in Millionen Euro) [Operating profit of savings banks in Germany in the years 1999 to 2018 (in millions of euros)]. Retrieved from https://de.statista.com/statistik/daten/studie/157024/umfrage/beschaeftigte-in-sparkassen-seit-dem-jahr-200 $0 /$

Conrad, A., Hoffmann, A., \& Neuberger, D. (2017). Physische und digitale Erreichbarkeit von Finanzdienstleistungen der Sparkassen [Physical and digital accessibility of financial services of savings banks], ThünenSeries of Applied Economic Theory - Working Paper, No. 149, Universität Rostock, Institut für Volkswirtschaftslehre, Rostock, Retrieved from http://hdl.handle.net/10419/156222

Damaschke, C., \& Giebe, C. (2020). Sparkassen-DataAnalytics: Den Datenschatz der Sparkassen-Finanzgruppe heben [Savingbanks-data-analytics: Raising the data treasure of the Savings Bank Finance Group]. In E. R. Utz (Eds.), Digitalisierung - "the next challenge” für Sparkassen Handlungsfelder zur künftigen Gestaltung des Geschäftsmodells in Sparkassen (pp. 139-154). Deutscher Sparkassenverlag GmbH, Stuttgart.

Drummer, D., Jerenz, A., Siebelt, P., \& Thaten, M. (2016). FinTech - Challenges and Opportunities How digitization is transforming the financial sector. McKinsey \& Company, (May), 1-7, Retrieved from http://www.mckinsey.com/industries/financial-services/our-insights/fintech-challenges-and-opportunities

Eigenkapitalrentabilität nach Steuern der Genossenschaftsbanken in Deutschland in den Jahren von 1994 bis 2018 [Return on equity after taxes of cooperative banks in Germany in the years 1994 to 2018]. Retrieved from https://de.statista.com/statistik/daten/studie/242274/umfrage/eigenkapitalrentabilitaet-der-kreditgenossensch aften-in-deutschland/

Eigenkapitalrentabilität nach Steuern der Sparkassen in Deutschland in den Jahren von 1994 bis 2018 [Return on equity after taxes of savings banks in Germany in the years 1994 to 2018]. Retrieved from https://de.statista.com/statistik/daten/studie/242273/umfrage/eigenkapitalrentabilitaet-der-sparkassen-in-deu tschland/

Entwicklung der Anzahl der Volksbanken und Raiffeisenbanken in Deutschland von 1970 bis 2019 
[Development of the number of Volksbanken and Raiffeisenbanken in Germany from 1970 to 2019]. Retrieved

https://de.statista.com/statistik/daten/studie/71931/umfrage/volksbanken-und-raiffeisenbanken---anzahl-derbanken-seit-1998/

Entwicklung der Cost-Income-Ratio der Genossenschaftsbanken in Deutschland in den Jahren von 1998 bis 2018 [Development of the cost-income ratio of cooperative banks in Germany in the years 1998 to 2018], https://de.statista.com/statistik/daten/studie/755282/umfrage/cost-income-ratio-der-genossenschaftsbanken-i n-deutschland/

Entwicklung der Cost-Income-Ratio der Sparkassen in Deutschland in den Jahren von 1998 bis 2018 [Development of the cost-income ratio of savings banks in Germany in the years 1998 to 2018], https://de.statista.com/statistik/daten/studie/197223/umfrage/cost-income-ratio-der-sparkassen-in-deutschla nd-seit-2007/

Giebe, C. (2019). The Chief Digital Officer-Savior for the Digitalization in German Banks? Journal of Economic Development, Environment and People, 8(3), 6-15. https://doi.org/10.26458/jedep.v8i3.633

Giebe, C., Hammerström, L., \& Zwerenz, D. (2019). Big Data \& Analytics as a sustainable Customer Loyalty Instrument in Banking and Finance. Financial Markets, Institutions and Risks, 3(4), 74-88. https://doi.org/10.21272/fmir.3(4).74-88.2019

Hammermann, A., \& Stettes, O. (2016). Qualifikationsbedarf und Qualifizierung: Anforderungen im Zeichen der Digitalisierung [Skills needs and qualification: requirements in the spirit of digitalisation]. IW policy paper (No. 3/2016). Institut der deutschen Wirtschaft (IW). German Economic Institute, Retrieved from http://hdl.handle.net/10419/127450

Hammerstöm, L., Zwerenz, D., \& Giebe, C. (2019). Taxonomy of an IIot Device Based upon Production Functions. European Journal of Economics and Business Studies, 5(2), 6-22. https://doi.org/10.26417/ejes.v5i2.p6-22

Hess, T., Matt, C., Benlian, A., \& Wiesböck, F. (2016). Options for formulating a digital transformation strategy. MIS Quarterly Executive, 15(2). Retrieved from https://aisel.aisnet.org/misqe/vol15/iss2/6

Ilie, O. M.., Popescu, C., \& Iacob, S. E. (2017). Transforming the Banking Organization in the Context of Digital Economy. Proceedings RCE 2017, 284-292. https://doi.org/10.18662/lumproc.rce2017.1.24

Kauffman, R. J., Weber, T. A. (2018). Special Section: The Digital Transformation of Vertical Organizational Relationships. Journal of Management Information Systems, 35(3), 837-839. https://doi.org/10.1080/07421222.2018.1481646

Liu, D. Y., Chen, S. W., \& Chou, T. C. (2011). Resource fit in digital transformation: Lessons learned from the CBC Bank global e-banking project. Management Decision, 49(10), 1728-1742. https://doi.org/10.1108/00251741111183852

Mavlutova, I., \& Volkova, T. (2019). Digital Transformation of Financial Sector and Challengies for Competencies Development. In 2019 7th International Conference on Modeling, Development and Strategic Management of Economic System (MDSMES 2019). Atlantis Press, https://dx.doi.org/10.2991/mdsmes-19.2019.31

Menrad, M. (2020). Systematic review of omni-channel banking and preview of upcoming developments in Germany. Innovative Marketing , 16(2), 104-125, https://doi.org/10.21511/im.16(2).2020.09

Moormann, J. (2000). Die Digitalisierung des Bankgeschäfts [The digitization of banking business]. In Informationstechnologie in Banken (pp. 3-16). Springer, Berlin, Heidelberg, https://doi.org/10.1007/978-3-642-56991-3_1

Peters, H. W. (2018). Bankenverband rechnet mit kräftigem Abbau von Filialen [Association of German Banks anticipates significant reduction in the number of branches]. In Frankfurter Allgemeine. Retrieved from https://www.faz.net/aktuell/wirtschaft/bankenverband-rechnet-mit-kraeftigem-abbau-von-filialen-15579480 .html?GEPC $=\mathrm{s} 81 \&$ GEPC $=\mathrm{s} 5$

Sebastian, I., Ross, J., Beath, C., Mocker, M., Moloney, K., \& Fonstad, N. (2017). How big old companies navigate digital transformation. MIS Quarterly Executive 16(3), 197-213. Retrieved from https://aisel.aisnet.org/misqe/vol16/iss3/6

Wolgast, M. (2016). Das gegenwärtige Niedrigzinsumfeld aus Sicht der Sparkassen [The current low interest 
rate environment from the point of view of savings banks]. Vierteljahrshefte zur Wirtschaftsforschung, 85(1), 11-29, https://doi.org/10.3790/vjh.85.1.11

\section{Copyrights}

Copyright for this article is retained by the author(s), with first publication rights granted to the journal.

This is an open-access article distributed under the terms and conditions of the Creative Commons Attribution license (http://creativecommons.org/licenses/by/4.0/). 